\title{
Fusion and Infection of Influenza and Sendai Viruses as Modulated by Dextran Sulfate: A Comparative Study
}

\author{
João Ramalho-Santos, ${ }^{1,2,4}$ and Maria C. Pedroso de Lima ${ }^{1,3}$ \\ Received January 3, 2001

\begin{abstract}
We have directly compared the effect of two types of dextran sulfate with distinct molecular weights $(500 \mathrm{kDa}$ and $5 \mathrm{kDa})$ on the fusion activity and infectivity of both Sendai and influenza viruses, two lipid-enveloped viruses that differ in their routes of entry into target cells. To correlate membrane merging and infectivity MDCK cells were used as targets for the viruses in both approaches. In either case pronounced inhibition of virus-cell interactions by dextran sulfate was only observed at low $\mathrm{pH}$, even though Sendai virus fuses maximally at $\mathrm{pH}$ 7.4. Although membrane merging could not be fully abolished, the inhibitory effect was always greater when the higher molecular weight dextran sulfate was used. The presence of this residual fusion activity, that could not be reduced even with high concentrations of agent, suggests that a limited number of binding sites for dextran sulfate may exist on the viral envelopes. The compounds also inhibited fusion of bound virions, and all results could be reproduced using erythrocyte ghosts as target membranes in the fusion assay, instead of MDCK cells. In agreement with these observations only the infecaffected by dextran sulfate, again the higher molecular weight compound showing a more pronounced inhibitory effect.
\end{abstract} \\ tivity of influenza virus (which requires a low $\mathrm{pH}$-dependent step to enter target cells) was
}

KEY WORDS: Influenza; Sendai; membrane fusion; dextran sulfate; infectivity; inhibition

ABBREVIATIONS: DMEM, Dulbecco's Modified Eagle Medium; D8, extran $8 \mathrm{kDa}$; D 500, dextran $500 \mathrm{kDa}$; DS 5, dextran sulfate $5 \mathrm{kDa}$; DS 500, dextran sulfate $500 \mathrm{kDa}$; HA, influenza virus hemagglutinin; MDCK-Madin-Darby canine kidney cells; pfu-plaque forming units; R18, octadecylrhodamine B chloride

\section{INTRODUCTION}

All lipid-enveloped viruses enter cells via a membrane fusion event that is usually dependent on one or more viral envelope proteins. However, there are two distinct routes of viral entry into a target cell. Thus, while some viruses (such as Sendai virus or HIV) fuse directly with the cell plasma membrane at neutral $\mathrm{pH}$, others (such as influenza virus) enter by receptor-mediated endocytosis. In this case, viral access to the target cell cytosol occurs following fusion between the viral envelope and the

\footnotetext{
${ }^{1}$ Center for Neuroscience and Cell Biology of Coimbra, University of Coimbra, Portugal

${ }^{2}$ Department of Zoology, University of Coimbra, Portugal.

${ }^{3}$ Department of Biochemistry, University of Coimbra, Portugal.

${ }^{4}$ To whom all correspondence should be addressed. Fax: + 351 (239) 826798; E-mail: jramalho@ci.uc.pt
} 
membrane of an intracellular compartment (the endosome). For influenza virus this event is mediated by the viral envelope hemagglutinin (HA), and is triggered by conformational changes in the protein that take place at the acidic $\mathrm{pH}$ normally found in the endosomal lumen (for reviews see Hoekstra and Lima, 1992; Hernandez et al., 1996; Ramalho-Santos and Lima, 1998.

The characterization of compounds with putative antiviral activity often focuses on the ability of these agents to inhibit viral entry by blocking the membrane fusion step that is necessary for infection (Cheetham et al., 1990; Yeagle et al., 1994; Gunther-Ausborn et al., 1995; Miao et al., 1995; Epand et al., 1997; Schoen et al., 1997). One such family of compounds consists of polysulfated molecules, such as heparin or dextran sulfate, that have attracted attention for their ability to inhibit HIV replication (for a review see Witvrouw and De Clercq, 1997). For this reason the effect of polysulfated molecules on the fusion activity of lipid-enveloped viruses has been studied in many systems, using, among others, both Sendai (Arnold et al., 1990; Ohki et al., 1991, 1992; Lüscher-Mattli et al., 1993; Zschörnig et al., 1993; Wagner et al., 1998) and influenza viruses (Lüscher-Mattli and Glück, 1990; Herrmann et al., 1992; Krumbiegel et al., 1992; Lüscher-Mattli et al., 1993), as well as a wide variety of target membranes.

When determining the effect of inhibitory agents on membrane merging promoted by enveloped viruses, fusion is usually assayed in isolation, and it is therefore difficult to establish whether inhibition of membrane fusion actually translates into a reduction of viral infection (Arnold et al., 1990; Ohki et al., 1991, 1992; Herrmann et al., 1992; Krumbiegel et al., 1992; Zschörnig et al., 1993; Wagner et al., 1998). Indeed, it is known that inhibition of fusion activity may not correlate with a lower production of infectious particles (McKenzie et al., 1987; Stamatatos and Düzgünes, 1994). On the other hand, while artificial target membranes, such as liposomes, are useful as models, they do not fully reflect the complexity of a biological membrane, and extrapolations from these systems must be made with great caution (LüscherMattli and Glück, 1990; Zschörnig et al., 1993). In fact, target membrane components are known to modulate the fusion activity of both Sendai (Nunes-Correia et al., 1998) and influenza viruses (Lima et al., 1995). Ideally, the effect of any potential antiviral agent on both fusion and infection should be assayed using the same target membrane. However, when these experiments are done concomitantly, viral infectivity is usually quantified in live cell monolayers, while membrane merging is monitored using a different target membrane, such as the more readily available erythrocyte ghosts (Lüscher-Mattli et al., 1993).

We have therefore set out to determine the effect of dextran sulfate on the fusion and infectivity of influenza and Sendai viruses, two lipid-enveloped viruses with distinct routes of cell entry, using the same target membrane to allow for direct comparisons. Thus, infection was quantified by plaque formation in MDCK monolayers, and, in parallel experiments, viral fusion activity towards the plasma membrane of these cells was also determined using the octadecylrhodamine B chloride (R18) fluorescence dequenching assay (Hoekstra et al., 1984). For control purposes erythrocyte ghosts were also occasionally used in fusion experiments as target membranes for both viruses. As was the case in other studies, we separately tested the effects of two types of dextran sulfate, with distinct molecular weights. 


\section{METHODS}

\section{Chemicals}

Dextran sulfate of $500 \mathrm{kDa}$ (DS 500) and $5 \mathrm{kDa}$ (DS 5), dextran of $8 \mathrm{kDa}$ (D8) and $500 \mathrm{kDa}$ (D 500) were obtained from Sigma (St. Louis, MO); as were all other chemicals used, unless stated otherwise.

\section{Viruses}

Influenza virus, A/PR/8/34 (H1N1) strain, was grown for $48 \mathrm{hr}$ at $37^{\circ} \mathrm{C}$ in the allantoic cavity of 11-day-old embryonated eggs, purified by discontinuous sucrose density gradient centrifugation and stored at $-70^{\circ} \mathrm{C}$ in phosphate buffered saline. Sendai virus ( $Z$ strain) was grown for $72 \mathrm{hr}$ in the allantoic cavity of 10 -day-old embryonated eggs, purified by differential centrifugation and stored at $-70^{\circ} \mathrm{C}$ in phosphate buffered saline.

\section{Cells}

MDCK cells were obtained from the American Type Culture Collection (ATCC, Rockville, MD) and grown in $75 \mathrm{~cm}^{2}$ culture flasks at $37^{\circ} \mathrm{C}$ in a humidified $5 \% \mathrm{CO}_{2}$ atmosphere with DMEM medium, supplemented with $10 \%$ heat-inactivated fetal calf serum, $100 \mu / \mathrm{ml}$ penicillin, $100 \mu \mathrm{g} / \mathrm{ml}$ streptomycin, $1 \mathrm{~g} / 1$ sodium bicarbonate, $10 \mathrm{mM}$ Hepes ( $\mathrm{pH}$ 7.4). The medium was changed regularly, and the cells used when confluent. For fusion experiments MDCK monolayers were washed twice with calcium/magnesium-free PBS, and the cells detached upon incubation (10 min, $37^{\circ} \mathrm{C}$ ) with a trypsin solution containing $138 \mathrm{mM} \mathrm{NaCl}, 2.7 \mathrm{mM} \mathrm{KCl}, 1 \mathrm{~g} / 1$ glucose, $0.02 \%(\mathrm{w} / \mathrm{v})$ EDTA, $0.05 \%(\mathrm{w} / \mathrm{v})$ trypsin, $0.58 \mathrm{~g} / 1$ sodium bicarbonate and $10 \mathrm{mM}$ sodium phosphate ( $\mathrm{pH} 7.4)$. MDCK cells in suspension were then pelleted (180 g, $10 \mathrm{~min}$ ), washed twice in PBS and resuspended in the experimental fusion buffer $\left(110 \mathrm{mM} \mathrm{NaCl}, 5 \mathrm{mM} \mathrm{KCl}, 2 \mathrm{mM} \mathrm{CaCl}, 1 \mathrm{mM} \mathrm{MgCl}_{2}, 10 \mathrm{mM}\right.$ glucose, $10 \mathrm{mM}$ sodium citrate, $10 \mathrm{mM}$ Mes and $10 \mathrm{mM}$ Hepes, $\mathrm{pH}$ 7.4). Cell viability was determined by trypan blue exclusion, and was routinely $85-95 \%$. To avoid any possible effects of cell death or aggregation, all experiments were limited to a maximum of $4 \mathrm{hr}$ following each MDCK cell preparation.

\section{Erythrocyte Ghosts}

For control experiments human erythrocyte ghosts were prepared by the method of Steck and Kant (1974). Following hypotonic lysis the membranes were resealed in $85 \mathrm{mM} \mathrm{NaCl}, 50 \mathrm{mM} \mathrm{KCl}, 5 \mathrm{mM} \mathrm{MgCl}_{2}, 10 \mathrm{mM}$ Hepes, $10 \mathrm{mM}$ Mes, $10 \mathrm{mM}$ sodium citrate, buffered at $\mathrm{pH}$ 7.4.

\section{Viral Fusion Activity}

Influenza and Sendai viruses were labeled with the fluorescent probe octadecylrhodamine B chloride (R18; Molecular Probes Inc., Eugene, OR) at a selfquenching concentration, as described previously (Hoekstra et al., 1984; RamalhoSantos et al., 1993, 1996). The final concentration of added probe corresponded to 
approximately 5 mole $\%$ of total viral lipid and that of ethanol was less than $1 \%(\mathrm{v} /$ v). The mixture was incubated in the dark for $30 \mathrm{~min}$ at room temperature. R18labeled virus was separated from non-inserted fluorophore by chromatography on Sephadex G-75 (Pharmacia, Uppsala, Sweden) using $150 \mathrm{mM} \mathrm{NaCl}, 10 \mathrm{mM}$ Hepes, pH 7.4 as elution buffer. The protein concentration of the labeled virus was determined by the Lowry assay.

Fusion was monitored continuously at $37^{\circ} \mathrm{C}$ as a function of $\mathrm{R} 18$ fluorescence dequenching, dependent on probe dilution into the plasma membrane of MDCK cells upon virus-cell fusion (Hoekstra et al., 1984; Ramalho-Santos et al., 1993, 1996). For influenza virus $2 \mu \mathrm{g}$ of viral protein were added to $5 \times 10^{6} \mathrm{MDCK}$ cells in a final volume of $2 \mathrm{ml}$ of experimental buffer at $\mathrm{pH} 7.4$. Following a $2 \mathrm{~min}$ incubation the $\mathrm{pH}$ was lowered to 5.0, and virus-cell fusion followed for $5 \mathrm{~min}$. For Sendai virus $5 \mu \mathrm{g}$ of viral protein were added to $5 \times 10^{6}$ MDCK cells in a final volume of $2 \mathrm{ml}$ of experimental buffer at $\mathrm{pH} 7.4$ or 5.0, and virus-cell fusion followed for $10 \mathrm{~min}$. Parallel experiments with human erythrocyte ghosts were carried out in basically the same manner for both viruses, using $100 \mu \mathrm{g}$ of target membrane protein $/ \mathrm{ml}$ in each assay.

In some experiments we sought to evaluate exclusively the fusion activity of bound virions. For this purpose influenza $(3 \mu \mathrm{g})$ and Sendai $(15 \mu \mathrm{g})$ viruses were incubated with $5 \times 10^{6} \mathrm{MDCK}$ cells for $1 \mathrm{hr}$ at $0^{\circ} \mathrm{C}$ and $\mathrm{pH}$ 7.4. The virus-cell mixture was then pelleted $\left(180 \mathrm{~g}, 10 \mathrm{~min}, 0^{\circ} \mathrm{C}\right)$, washed twice and resuspended in a small volume $( \pm 100 \mu \mathrm{l})$ of experimental buffer. This cell pellet was added to $1.9 \mathrm{ml}$ of buffer at $37^{\circ} \mathrm{C}$, and fusion of bound virus monitored for $5 \mathrm{~min}$ at $\mathrm{pH} 5.0$ (influenza), or $10 \mathrm{~min}$ at $\mathrm{pH} 7.4$ or 5.0 (Sendai).

In all experiments the fluorescence scale was calibrated such that the initial fluorescence of R18 labeled virus and cells was set at $0 \%$ fluorescence, and the value obtained by detergent lysis after each experiment with Triton X-100 (maximal probe dilution), at a final concentration of $1 \%(\mathrm{v} / \mathrm{v})$, was set at $100 \%$ fluorescence. Fluorescence measurements were performed in a SPEX Fluorolog spectrofluorometer, with excitation at $560 \mathrm{~nm}$ and emission at $590 \mathrm{~nm}$. The sample chamber was equipped with a magnetic stirring device, and the temperature was maintained at $37^{\circ} \mathrm{C}$ with a thermostatted circulating water bath.

\section{Binding and Cell Association}

To quantify virus-cell binding, influenza virus ( $2 \mu \mathrm{g}$ of viral protein) was added to $5 \times 10^{6} \mathrm{MDCK}$ cells in a final volume of $2 \mathrm{ml}$. The virus-cell suspension was then incubated at $37^{\circ} \mathrm{C}$ and $\mathrm{pH} 7.4$ for $2 \mathrm{~min}$. For Sendai virus $5 \mu \mathrm{g}$ of viral protein were added to $5 \times 10^{6}$ MDCK cells in a final volume of $2 \mathrm{ml}$ and the mixture incubated for $1 \mathrm{hr}$ at $0^{\circ} \mathrm{C}$ and $\mathrm{pH} 7.4$ or 5.0. Under these conditions fusion does not take place. Following these incubations the cells were centrifuged $\left(180 \mathrm{~g}, 10 \mathrm{~min}, 0^{\circ} \mathrm{C}\right)$ and fluorescence measured in the pellet and supernatant after addition of Triton X-100 $(1 \% \mathrm{v} / \mathrm{v})$. Binding was calculated as the percentage of fluorescence in the pellet, relative to total fluorescence (pellet + supernatant). Cell association (bound + fused virions) was also measured for influenza virus. In this case the virus-cell incubation at $\mathrm{pH} 7.4$ was followed by a further $5 \mathrm{~min}$ incubation at $\mathrm{pH} 5.0\left(37^{\circ} \mathrm{C}\right)$. The cells 
were then centrifuged $\left(180 \mathrm{~g}, 10 \mathrm{~min}, 0^{\circ} \mathrm{C}\right)$, and cell association calculated as described above (Lima et al., 1995).

\section{Viral Infectivity}

Infectivity was determined as described previously (Compans and Roberts, 1994). Briefly, MDCK cells were grown to confluency in 12-compartment multiwells and incubated for $2 \mathrm{hr}\left(37^{\circ} \mathrm{C}\right)$ with $0.5 \mathrm{ml}$ of socially diluted viral suspensions in PBS. The cells were then washed twice in PBS to remove unbound virions, overlayed with $1 \mathrm{ml}$ of agar $(1 \% \mathrm{w} / \mathrm{v})$ in DMEM containing $5 \mu \mathrm{g} / \mathrm{ml}$ trypsin, and returned to the incubator. Plaques were counted 2-5 days post infection. In experiments using dextran or dextran sulfate the agents were present at a fixed concentration throughout the experiment.

\section{RESULTS}

\section{Inhibition of Influenza Virus Fusion Activity by Dextran Sulfate}

The effect of DS 500 and DS 5 on influenza virus fusion activity towards the plasma membrane of MDCK cells was determined. When added to the fusion medium prior to the low $\mathrm{pH}$ triggering of influenza fusion, dextran sulfate inhibited membrane merging (Fig. 1). The higher molecular weight DS 500 was noticeably more potent, reducing fusion at a concentration as low as $5 \mu \mathrm{g} / \mathrm{ml}$, and inhibiting the process by a maximum of $\pm 73 \%$. On the other hand, an effect of DS 5 was only detected at $15 \mu \mathrm{g} / \mathrm{ml}$, and the inhibition obtained with this lower molecular weight dextran sulfate was never above $\pm 41 \%$. Interestingly, with both types of dextran sulfate some (none negligible) influenza virus fusion activity was always maintained; i.e., membrane merging could not be inhibited below a certain value, characteristic for each type of DS (Fig. 1). This inhibition was specific for these sulfated compounds, since the presence of equivalent concentrations of D 8 or D 500 in the medium had no effect on viral fusion activity (data not shown). On the other hand, inhibition by dextran sulfate (both DS 500 and DS 5) was similar when erythrocyte ghosts were used as target membranes in the fusion assay (data not shown). The inhibitory effect was not enhanced by preincubating virions or cells with dextransulfate, which was equally potent (with DS 500 always showing a greater inhibitory effect) towards prebound virons (data not shown).

Virus-cell interactions were clearly affected by dextran sulfate only at low $\mathrm{pH}$. Viral binding (at neutral $\mathrm{pH}$ ) did not change in the presence or absence of the agents, while cell association was greatly reduced, again DS 500 showing an increased inhibitory effect when compared to DS 5 (Table 1). Remarkably, DS 500 reduced cell association to a value below what was observed for binding, suggesting that this compound might cause some viral dissociation.

Often overlooked is the fact that characterization of any new fusion system studied with the R18 assay should involve careful controls, to determine if any nonspecific probe transfer takes place from the virions to the target membranes, leading to a false positive signal. This is accomplished by proving that the virus can be 


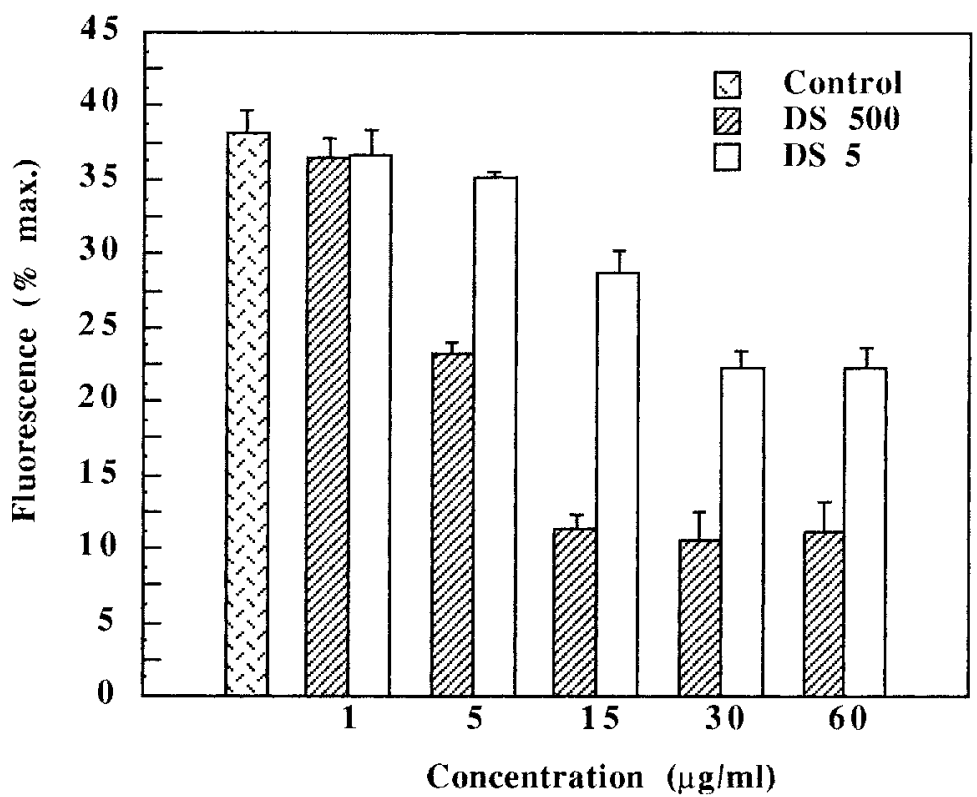

Fig. 1. Effect of dextran sulfate on the fusion activity of influenza virus. R18labeled influenza virus $(1 \mu \mathrm{g}$ viral protein $/ \mathrm{ml})$ was added to $5 \times 10^{6}$ MDCK cells at $37^{\circ} \mathrm{C}$ and $\mathrm{pH} 7.4$. The medium also contained DS 500 or DS 5 at the indicated concentrations $(\mu \mathrm{g} / \mathrm{ml})$. Following a short period of incubation to allow viruscell binding ( $2 \mathrm{~min}$ ) the medium $\mathrm{pH}$ was adjusted to 5.0, and the extent of $\mathrm{R} 18$ dequenching calculated after $5 \mathrm{~min}$. The average $\pm \mathrm{SD}$ of 6 independent experiments is presented. Higher concentrations of dextran sulfate had no further inhibitory effect (data not shown).

maintained in close contact with the target membrane (i.e., bound) without major R18 dequenching, at least in the time frame used for the assay. For this purpose, influenza virions were irreversibly inactivated by preincubation $\left(1 \mathrm{hr}, 37^{\circ} \mathrm{C}, \mathrm{pH} 5.0\right)$ in the absence of target membranes. This treatment precociously triggers the conformation change in the viral HA, and renders the virions fusion-incompetent (Ramalho-Santos et al., 1993, 1996; Ramalho-Santos and Lima, 1998). Inactivated

Table 1. Effect of Dextran Sulfate on Influenza Virus Binding and Cell Association to MDCK Cells ${ }^{a}$

\begin{tabular}{lcccc}
\hline & $\mathrm{pH}$ & Control & DS 500 & DS 5 \\
\hline Binding (\%) & 7.4 & $32.6 \pm 1.9$ & $31.6 \pm 1.3$ & $32.3 \pm 1.5$ \\
Cell Association $(\%)$ & $7.4 / 5.0$ & $55.0 \pm 2.0$ & $25.0 \pm 1.1$ & $33.2 \pm 2.2$ \\
\hline
\end{tabular}

${ }^{a} \mathrm{R} 18$-labeled influenza virus $(2 \mu \mathrm{g})$ was added to $5 \times 10^{6} \mathrm{MDCK}$ cells, in a final volume of $2 \mathrm{ml}$ at $37^{\circ} \mathrm{C}$. Virus-cell binding was quantified following a $2 \mathrm{~min}$ incubation at $\mathrm{pH}$ 7.4. In cell association experiments, following the incubation at neutral $\mathrm{pH}$ the medium was acidified, and the mixture further incubated at $\mathrm{pH} 5.0$ for $5 \mathrm{~min}$ (see Methods). In some experiments DS 500 and DS 5 were also included $(15 \mu \mathrm{g} / \mathrm{ml})$. The average of at least 3 independent experiments $( \pm \mathrm{SD})$ is presented. Higher concentrations of dextran sulfate had no further effect (data not shown). 
virions were still able to bind to MDCK cells $(29.8 \pm 1.8)$ and the value obtained was essentially identical to that of controls assayed simultaneously $(31.1 \pm 1.3)$. On the other hand, inactivated influenza virus only showed residual fusion activity (less than $8 \%$, data not shown), thus suggesting that unspecific R18 transfer does not affect the observations in this fusion system.

\section{Inhibition of Sendai Virus Fusion by Dextran Sulfate}

Fusion of Sendai virus with MDCK cells was maximal at $\mathrm{pH} 7.4$ (data not shown), similarly to what is observed when other biological target membranes are used (Ohki et al., 1991, 1992; Lima et al., 1992). However, at neutral pH the presence of DS 5 and DS 500 in the medium had no effect on viral fusion activity (data not shown). This result was obtained when the compounds were added shortly before the virions, and when either fusion partner was incubated with dextran sulfate prior to fusion (data not shown). Although Sendai virus fusion activity was much lower $(\sim 14.2 \%)$ at $\mathrm{pH} 5.0$ than at $\mathrm{pH} 7.4(\sim 32.9 \%)$, viral fusion at acidic $\mathrm{pH}$ was inhibited by both DS 5 and DS 500 (Fig. 2). Despite the fact that the concentrations required to observe any inhibitory effect were higher than for influenza virus, the pattern was otherwise very similar. Namely, the effect was more pronounced for DS 500 (maximum inhibition of $\sim 66 \%$ ) than for DS 5 (maximum inhibition of $\sim 33 \%$ ), and a minimal residual fusion activity was maintained even at high dextran sulfate

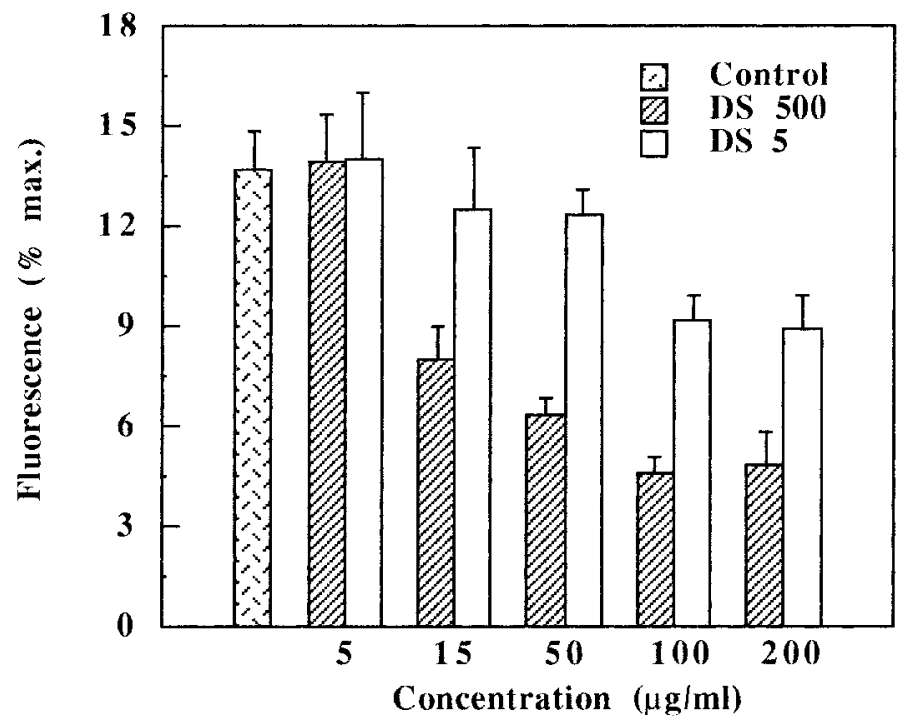

Fig. 2. Effect of dextran sulfate on the fusion activity of Sendai virus at low $\mathrm{pH}$. R18-labeled Sendai virus $(5 \mu \mathrm{g}$ viral protein $/ \mathrm{ml})$ was added to $5 \times 10^{6} \mathrm{MDCK}$ cells at $37^{\circ} \mathrm{C}$ and $\mathrm{pH}$ 5.0. The medium also contained DS 500 or DS 5 at the indicated concentrations $(\mu \mathrm{g} / \mathrm{ml})$. Fusion extents, as monitored by R18 dequenching, were calculated after $10 \mathrm{~min}$, and the average $\pm \mathrm{SD}$ of 5 independent experiments is presented. Higher concentrations of dextran sulfate had no further inhibitory efect (data not shown). 


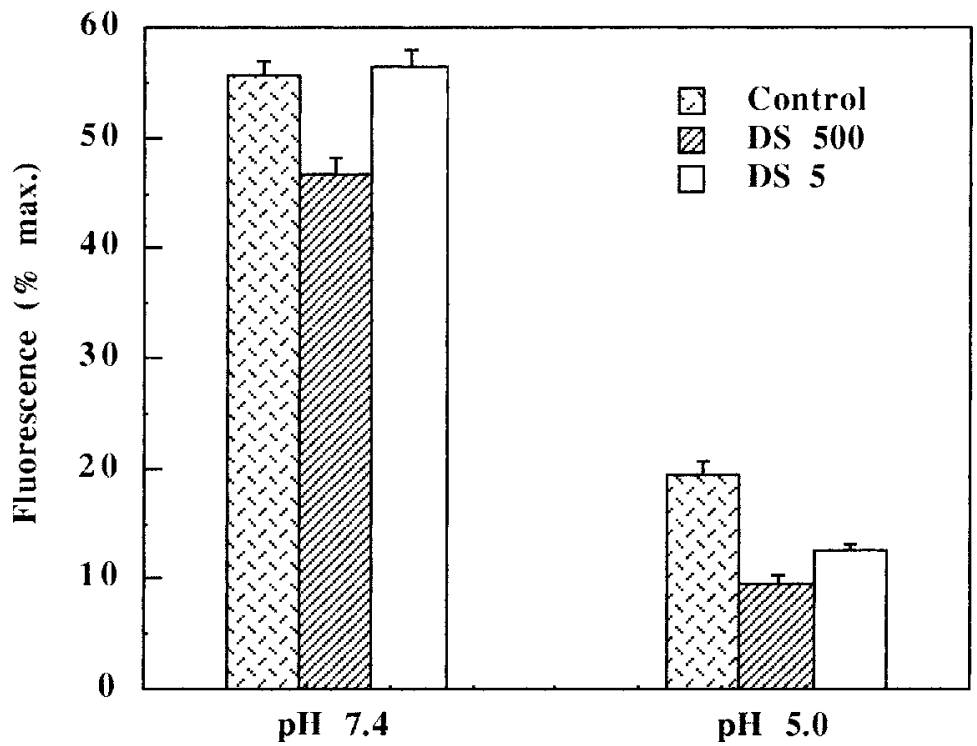

Fig. 3. Effect of dextran sulfate on the fusion activity of Sendai virus prebound to MDCK cells. R18-labeled Sendai virus $(15 \mu \mathrm{g}$ viral protein $/ \mathrm{ml})$ was added to $2 \mathrm{ml}$ of buffer containing $5 \times 10^{6}$ MDCK cells at $0^{\circ} \mathrm{C}$ and $\mathrm{pH} 7.4$. Following a $1 \mathrm{hr}$ incubation at $0^{\circ} \mathrm{C}$ the cells were pelleted, and the fusion activity of bound virions was assayed at $\mathrm{pH} 7.4$ or 5.0 , in the presence or absence of dextran sulfate $(0.5 \mathrm{mg} / \mathrm{ml})$. Fusion extents, as monitored by R18 dequenching, were calculated after $10 \mathrm{~min}$, and the average $\pm \mathrm{SD}$ of 6 independent experiments is presented.

concentrations. Inhibition was also not enhanced by preincubating virions or cells with dextran sulfate (data not shown), and the inhibitory effect of dextran sulfate towards prebound Sendai virions was similar (Fig. 3), although in this case a slight decrease in fusion activity $(\sim 18 \%)$ was observed with DS 500 at $\mathrm{pH} 7.4$.

Binding of Sendai virus to MDCK cells was greatly potentiated at low $\mathrm{pH}$ (Table 2). This is most likely an unspecific effect, probably due to an increase in viral hydrophobicity (Ramalho-Santos et al., 1994a, b), since it does not translate

Table 2. Effect of $\mathrm{pH}$ and Dextran Sulfate on Binding of Sendai Virus to MDCK Cells ${ }^{a}$

\begin{tabular}{cccc}
\hline $\mathrm{pH}$ & Control & DS 500 & DS 5 \\
\hline 7.4 & $23.9 \pm 1.8$ & $23.4 \pm 1.2$ & $23.3 \pm 1.7$ \\
5.0 & $42.3 \pm 1.9$ & $19.2 \pm 1.4$ & $34.8 \pm 1.1$ \\
\hline
\end{tabular}

${ }^{a} \mathrm{R} 18$-labeled Sendai virus $(5 \mu \mathrm{g})$ was added to $5 \times 10^{6}$ MDCK cells at $0^{\circ} \mathrm{C}$ and $\mathrm{pH} 7.4$ or 5.0. In some experiments DS 500 or DS $5(0.5 \mathrm{mg} / \mathrm{ml})$ were also included. Binding percentage was determined after a $1 \mathrm{hr}$ incubation (see Methods). The average of at least 3 independent assays $( \pm \mathrm{SD})$ is presented. Higher concentrations of dextran sulfate had no further effect (data not shown). 
into a higher fusion activity at pH 5.0 (see above). Dextran sulfate modulated viral binding in a manner that mirrored its efect on fusion; i.e., binding at neutral $\mathrm{pH}$ was unaffected, while binding at pH 5.0 was inhibited by DS 500 and, with less potency, by DS 5 (Table 2).

Other experiments demonstrated that the presence of equivalent concentrations of D 8 and D 500 in the medium did not affect Sendai virus fusion with MDCK cells in any way (data not shown). In addition, Sendai virus pretreated with trypsin before being added to MDCK cells was still able to bind the target membrane, but could no longer fuse with it (at both $\mathrm{pH} 7.4$ and 5.0). Therefore, it seems reasonable to conclude that increases in R18 fluorescence monitored in these assays were due to membrane fusion, and not to non-specific probe transfer (data not shown). Finally, it should be noted that inhibition of Sendai virus fusion activity by dextran sulfate (both DS 500 and DS 5) was similar when erythrocyte ghosts were used as target membranes (data not shown).

\section{Effect of Dextran Sulfate on Influenza and Sendai Virus Infectivity}

The effect of dextran sulfate on viral replication was determined as a function of infectivity in MDCK monolayers, monitored with the plaque assay. In this manner fusion and infection are quantified using the same target membranes. However, inhibition of viral replication by dextran sulfate only occurred for influenza virus, notably using DS 500, while Sandai virus infectivity was unaffected in the presence of the polysulfated anions (Table 3).

Table 3. Effect of Dextran Sulfate on the Infectivity of Influenza and Sendai Viruses ${ }^{a}$

\begin{tabular}{lc}
\hline & $\begin{array}{c}\text { Infectivity } \\
(\mathrm{pfu} / \mathrm{ml})\end{array}$ \\
\hline Influenza & $6.4 \times 10^{7}$ \\
Control & $4.0 \times 10^{6}$ \\
DS $500(15 \mu \mathrm{g} / \mathrm{ml})$ & $2.2 \times 10^{7}$ \\
DS $5(15 \mu \mathrm{g} / \mathrm{ml})$ & \\
Sendai & $8.1 \times 10^{6}$ \\
Control & $8.3 \times 10^{6}$ \\
DS $500(0.5 \mathrm{mg} / \mathrm{ml})$ & $7.9 \times 10^{6}$ \\
DS $5(0.5 \mathrm{mg} / \mathrm{ml})$ & \\
\hline
\end{tabular}

${ }^{a}$ Viral infectivity was determined as described in Methods. In all cases dextran sulfate was added to the cells before the virus, and maintained in the culture medium throughout. Higher concentrations of dextran sulfate (up to $100 \mu \mathrm{g} / \mathrm{ml}$ for influenza, and $2 \mathrm{mg} / \mathrm{ml}$ in the case of Sendai) did not further inhibit viral infectivity (data not shown). The presence of equivalent concentrations of dextran (both D 8 and D 500) had no effect (data not shown). Representative data from 4 independent experiments is presented. 


\section{DISCUSSION}

In this study we have directly and systematically compared the fusion activity and infection of influenza and Sendai viruses as affected by two types of dextran sulfate, using MDCK cells as viral targets. The results obtained are consistent with previously published data regarding the effect of these polyanions on virus fusion (Arnold et al., 1990; Lüscher-Mattli and Glück, 1990; Ohki et al., 1991, 1992; Herrmann et al., 1992; Krumbiegel et al., 1992; Lüscher-Mattli et al., 1993; Zschörnig et al., 1993; Wagner et al., 1998). In addition, some new information has also emerged.

Inhibition of membrane fusion in our system was always much more pronounced with DS 500 than DS 5, in agreement with a previous study for influenza virus (Krumbiegel et al., 1992), but in contrast to the modest differences reported in other systems, using either virus and dextran sulfate of different molecular weights (Lüscher-Mattli and Glück, 1990; Ohki et al., 1991; Lüscher-Mattli et al., 1993; Zschörnig et al., 1993). Dextran sulfate seemed to affect even virions that had been previously bound to MDCK cells, and the effect of the polysulfated molecules was almost exclusively dependent on the acidic $\mathrm{pH}$ of the medium (see below). For both viruses a residual fusion activity was always observed, and even high concentrations of dextran sulfate could not totally abolish, or even further reduce, membrane merging. Furthermore, in all cases this residual fusion was always higher for DS 5 than DS 500, i.e., even higher concentrations of DS 5 did not cause the same inhibitory effect as DS 500. Given that dextran sulfate has been suggested to bind to viral membranes (Lüscher-Mattli and Gluck, 1990; Ohki et al., 1991, 1992), this result indicates that there may be a limited number of binding sites for dextran sulfate on the viral envelope. Since dextran sulfate does not seem to affect the low $\mathrm{pH}$-dependent conformational change of the influenza HA (Krumbiegel et al., 1992), or interact directly with Sendai virus envelope proteins (Zschörnig et al., 1993), polysulfated molecules bound to the virions might inhibit membrane merging by acting as a steric barrier to the final approach, which would also explain why the larger DS (DS 500) has always a significantly greater effect than DS 5. Although dextran sulfate has been suggested to inhibit virus-cell binding (Herrmann et al., 1992), this effect probably has little physiological relevance, given that both viruses usually bind a target cell at neutral pH (Hoekstra and Lima, 1992; Ramalho-Santos and Lima, 1998), and that this interaction is not affected in the presence of dextran sulfate.

In previous studies dextran sulfate was shown to inhibit Sendai virus fusion activity at neutral $\mathrm{pH}$, although the effect was always much more pronounced at low pH (Ohki et al., 1991, 1992). One difference in the experimental approach is that our fusion media contained divalent cations, which could interact with dextran sulfate, and possibly affect its potency. However, this seems unlikely, since $2 \mathrm{mM}$ $\mathrm{CaCl}_{2}$ does not diminish the effect of dextran sulfate on the binding and fusion of influenza virus with erythrocyte ghosts (Krumbiegel et al., 1992). Furthermore, in our system dextran sulfate has an inhibitory effect at low $\mathrm{pH}$ similar to what has been reported with divalent cation-free media (Ohki et al., 1991, 1992). Curiously, this inhibition is in the same range as the effect observed for influenza virus. It has been suggested that acidification neutralizes negative charges on the virus surface, 
thus enhancing binding of the negatively charged dextran sulfate (Lüscher-Mattli and Glück, 1990; Ohki et al., 1991, 1992; Wagner et al., 1998). Indeed, as mentioned above, dextran sulfate only inhibited influenza or Sendai virus interactions with MDCK cells at low pH. However, while in the case of influenza this effect may be important in terms of viral infection, the same cannot be stated for Sendai virus. In this regard it is important to note that, while Sendai virus binds more avidly to target membranes at low $\mathrm{pH}$, a process also inhibited by dextran sulfate, this is probably due to an unspecific increase in viral hydrophobicity (Ramalho-Santos et al., 1994a, b). Moreover, increased binding at a physiologically relevant low $\mathrm{pH}$ only translates into a higher fusion activity when negatively charged liposomes (Zschörnig et al., 1993), rather than biological membranes (this study, see also Ohki et al., 1991, 1992; Lima et al., 1992), are used as targets.

Inhibition of influenza virus fusion activity by DS 5 and DS 500 could be directly correlated with viral infection, which was expected, since this virus requires a low pH step to enter target cells (Lüscher-Mattli et al., 1993). On the other hand, given that Sendai virus fuses directly with the cell plasma membrane at neutral $\mathrm{pH}$, it was not forseeable that DS 500 or DS 5 would inhibit viral entry in vivo, and that was indeed the case (Lüscher-Mattli et al., 1993). It seems reasonable to assume that, for an agent such as dextran sulfate to potently inhibit viral infectivity, it must severely hinder viral fusion. Thus, it is unlikely that even the relatively modest effects of dextran sulfate on the fusion of Sendai virus at neutral $\mathrm{pH}$ reported previously (Ohki et al., 1991, 1992), would translate into an effective inhibition of infectivity. It is therefore probable that modulation of Sendai virus fusion activity by dextran sulfate, although important in addressing questions related to the viral fusion activity itself (Arnold et al., 1990; Ohki et al., 1991, 1992; Zschörnig et al., 1993; Wagner et al., 1998), has little relevance in terms of inhibiting cell infection by this virus, an observation that might be extrapolated to other members of the paramyxovirus family.

Finally, since the effect of dextran sulfate on membrane fusion was similar when MDCK cells and erythrocyte ghosts were used as target membranes, it is reasonable to assume that the more readily available ghosts are good models to predict the potency of antiviral agents that affect viral fusion activity. Infectivity quantified in cell monolayers and fusion monitored using erythrocyte membranes (Lüscher-Mattli et al., 1993) are therefore valid experimental approaches to correlate viral infection and membrane merging.

\section{ACKNOWLEDGMENTS}

This work was supported by FCT (Portugal).

\section{REFERENCES}

Arnold, K., Flanagan, T. D., and Ohki, S. (1990) Biomed. Biochim. Acta 49:633-635.

Cheetham, J. J., Epand, R. M., Andrews, M., and Flanagan, T. D. (1990) J. Biol. Chem. 265:1240412409.

Compans, R. W. and Roberts, P. C. (1994) Methods Cell Biol. 43:3-42. 
Epand, R. F., Moroder, L., Lutz, J., Flanagan, T. D., Nir, S., and Epand, R. M. (1997) Biochim. Biophys. Acta 1327:259-268.

Gunther-Ausborn, S., Praetor, A., and Stegmann, T. (1995) J. Biol. Chem. 270:29279-29285.

Hernandez, L. D., Hoffmann, L. R., Wolfsberg, T. G., and White, J. (1996) Annu. Rev. Cell Dev. Biol. 12:627-661.

Herrmann, A., Korte, T., Arnold, K., and Hillebrecht, B. (1992) Antiviral Res. 19:295-311.

Hoekstra, D., de Boer, T., Klappe, K., and Wilschut, J. (1984) Biochemistry 23:5675-5681.

Hoekstra, D. and Lima, M. C. P. (1992) Adv. Memb. Fluid. 6:71-97.

Krumbiegel, M., Dimitrov, D. S., Puri, A., and Blumenthal, R. (1992) Biochim. Biophys. Acta 1110: $158-164$

Lima, M. C. P., Ramalho-Santos, J., Martins, M. F., Carvalho, A. P., Bairos, V., and Nir, S. (1992) Eur. J. Biochem. 205:181-186.

Lima, M. C. P., Ramalho-Santos, J., Flasher, D., Slepushkin, V. A., Nir, S., and Düzgünes, N. (1995) Biochim. Biophys. Acta 1236:323-330.

Lüscher-Mattli, M. and Glück, R. (1990) Antiviral Res. 14:39-50.

Lüscher-Mattli, M., Glück, R., Kempf, C., and Zanoni-Grassi, M. (1993) Arch. Virol. 130:317-326.

McKenzie, R. C., Epand, R. M., and Johnson, D. C. (1987) Virology 159:1-9.

Miao, L., Stafford, A., Nir, S., Turco, S. J., Flanagan, T. D., and Epand, R. M. (1995) Biochemistry 34:4676-4683.

Nunes-Correia, I., Ramalho-Santos, J., and Lima, M. C. P. (1998) Biosci. Rep. 18: 59-68.

Ohki, S., Arnold, K., Srinivasakumar, N., and Flanagan, T. D. (1991) Biomed. Biochim. Acta 50:199206.

Ohki, S., Arnold, K., Srinivasakumar, N., and Flanagan, T. D. (1992) Antiviral Res. 18:163-177.

Ramalho-Santos, J., Nir, S., Düzgünes, N., Carvalho, A. P., and Lima, M. C. P. (1993) Biochemistry 32:2771-2779.

Ramalho-Santos, J., Negrão, R., and Lima, M. C. P. (1994a) Biochem. Mol. Biol. Inter. 32:1121-1127.

Ramalho-Santos, J., Negrão, R., and Lima, M. C. P. (1994b) Biosci. Rep. 14:15-24.

Ramalho-Santos, J., Lima, M. C. P., and Nir, S. (1996) J. Biol. Chem. 271:23902-23906.

Ramalho-Santos, J. and Lima, M. C. P. (1998) Biochim. Biophys. Acta 1376:147-154.

Schoen, P., Corver, J., Meijer, D. K., Wilschut, J., and Swart, P. J. (1997) Biochem. Pharmacol. 53: 995-1003.

Stamatatos, L. and Düzgünes, N. (1994) J. Gen. Virol. 74:1043-1054.

Steck, T. L. and Kant, J. A. (1974) Methods Enzymol. 31:172-180.

Wagner, M., Flanagan, T. D., and Ohki, S. (1998) Antiviral Res. 39:113-127.

Witvrouw, M. and De Clercq, E. (1997) Gen. Pharmacol. 29:497-511.

Yeagle, P. L., Smith, F. T., Young, J. E., and Flanagan, T. D. (1994) Biochemistry 33:1820-1827.

Zschörnig, O., Arnold, K., and Ohki, S. (1993) Biochim. Biophys. Acta 1148:1-6. 